\title{
Synthesis, Characterization and Analysis of Metal Complexes and their Inhibitor, and Anti-Microbial Activities
}

\author{
N. Srividhya, Ignatius Navis Karthika, K. Kavipriya
}

\begin{abstract}
Metal(II) chelates of Schiff bases resulting from the condensation 4-Amino-1,5-dimethyl-2-phenyl-1,2-dihydro-3H-pyrazol-3-one with 2- amino 3- base, carboxaldehyde and characterised by means of $1 \mathrm{H}$ magnetic resonance, FT- IR, UV-Vis and EPR spectral studies. The complexes ar of the variety M(-4AAP)2 [where $\mathrm{M}=\mathrm{Cu}(\mathrm{II}), \mathrm{Co}(\mathrm{II}))$,]. The metal atom is coordinated to atomic quantity 7 and factor atoms of the Schiff base substance. The free substance and its steel complexes have been screened for his or her medication activity. The effects indicate that the copper complexes are having substance vital recreation than its ligands towards some microorganisms under same experimental conditions. They additionally showcase protein properties. All the sparkling equipped compounds had been examined for inhibitor activity, the Schiff base substance and its metal complexes confirmed sensible activity.
\end{abstract}

Key words: 4 -Aminoantipyrine, 2- amino 3-pyridine, Antimicrobial studies,metal complex, Antioxidant studies.

\section{INTRODUCTION}

Schiff bases are crucial classification of compounds which can likewise be utilized in a scope of studies, similar to characteristic combination, impetus and medication style [1] and models for fiery destinations of metalloenzymes. They're the major flexible bunch of chelators for effortless act of metal-natural half and half materials [2], single particle predominantly essentially based magnets [3], remarkably porous materials, optoelectronic devices, and sensors [4]. The synthesis of 4-aminoantipyrine derivatives have attracted the eye of many evaluation groups thanks to their plausible organic activities. During this context, huge spectra of bioactive 4-aminoantipyrine derivatives and their metal complexes are investigated and diversities of bioactivities like analgesic, anti-inflammatory, anti-microbial, and malignant tumor recreation are rumored. two The growing microorganism resistance to antibiotics may also be a imperative necessity that inculcates the are seeking for for new compounds with doable results against mortify microorganism and fungi. The premier glorious advances in fortifying chemistry are made when heterocyclic compounds

Revised Manuscript Received on November 19, 2019

Dr.N.Srividhya, Assistant Professor in the Department of Chemistry, a PSNA College of Engineering and Technology, Dindigul,TamilNadu, India. (Email: vidhyahari11@gmail.com)

Dr. Ignatius Navis Karthika, Assistant Professor in the Department of Chemistry, at PSNA College of Engineering and Technology, Dindigul,TamilNadu, India.(Email: i.n.karthika@gmail.com)

Dr. K.Kavipriya, Assistant Professor in the Department of Chemistry at PSNA College of Engineering and Technology, Dindigul, Tamilnadu, India. (Email: seenikavi@yahoo.co.in)
Battle a significant job in law natural exercises. Heterocyclic moieties may also be resolved in a very substantial quantity of compounds that show natural entertainment Anti-pyrine (N-heterocyclic compound) and its subordinates display a monster vacillate of organic events and uses. As of their eye catching auxiliary decisions likewise in light of the fact that the natural action, a monster change of steel edifices got from anti-pyrine subsidiaries are supposed. Pyrazolone-based ligands show adjustable complexing conduct and a fluctuate of coordination opportunities to metallic focuses. Obvious of natural significance of Schiff base got from the buildup of 4-aminoantipyrine inferred with severa substitution its motivations in numerous fields, inside the blessing examination it's thought to incorporate the metallic edifices with progress metallic particles like $\mathrm{Co}(\mathrm{II}), \mathrm{Cu}(\mathrm{II})$.it's so of pastime to carryout investigations to grasp however a remember putting and its metallic advanced show the exercise in microorganism and flora pastime and additionally the spectral homes show the pastime in inhibitor studies of the inorganic complex.

\section{EXPERIMENTAL}

The chemical used for the preparation of ligand are Aldrich and sigma.Various physical measurements (FT-IR, ${ }^{1}$ H NMR, UV-Vis, EPR) are used and biological studies (Antimicrobial, Antioxidant, activities) are carried out.

A. Synthesis of ligand [(E)-4-((2-hydroxy-5methylbenzylidene)amino)-1,5-dimethyl-2-phenyl-1H-pyrazo l-3(2H)-one]

A salt of 4-Amino-1,5-dimethyl-2-phenyl-1,2-dihydro-3H-pyrazol-3one $(0.4065 \mathrm{~g}$, one $\mathrm{mmol})$ in ethyl alcohol $(5 \mathrm{ml})$ was once extra to an reply of 2- Amino 3- alkali carboxaldehyde $(0.2442 \mathrm{~g}$, one $\mathrm{mmol})$ in ethyl alcohol $(5 \mathrm{ml})$. The response mixture used to be stirred for two hrs at temperature then heated to reflux for three hrs and unbroken at $273 \mathrm{~K}$ for $4 \mathrm{hrs}$. The characteristic pale-green precipitate got was once filtered and two recrystallised via dissolving in methyl alcohol (m.p. $160 \mathrm{oC} \mathrm{K})$. Yield: Eighty three percentage. 


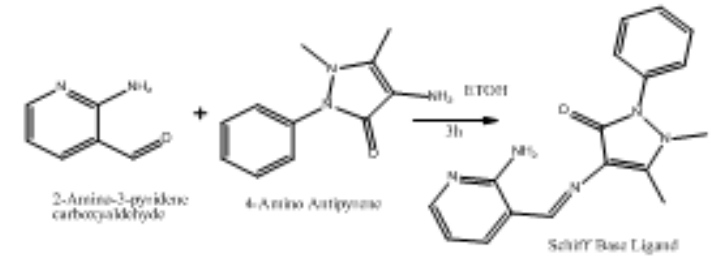

Fig.1. Synthesis of Schiff base Ligand (L1)

\section{B. Amalgamate, of metal complexes}

An ethyl alcohol answer of Metal (II) acetate \& III chloride (1 mmol, fifteen millilitre liquid ethyl alcohol) was superimposed dropwise to a stirred ethanol answer of the Schiff base matter. The ensuing answer was gently heated for five hrs with constant stirring. The precipitate solid was filtered, washed with quandary, so ethyl alcohol followed by ether and dried in vacuo. Yield: $70 \%$; M.p. $300^{\circ} \mathrm{C}$. The advanced is soluble in DMF and DMSO, and is partly soluble in chloroform and wood spirit.

Schiff Base Ligand (L1)

Metal $-\left[\mathrm{Cu}(\mathrm{OAC}]_{2}, \mathrm{Co}(\mathrm{OAC})_{2}\right.$, ][(E)-4-((2-hydroxy-5-methylbenzylid ene)amino)-1,5-dimethyl-2-phenyl-1 H-pyrazol-3(2H)-one]

Fig.2.Synthesis of Schiff base metal (II) Complexes

\section{RESULTS AND DISCUSSION}

Metal(II) chelates of Schiff bases derived from the condensation of 4-Amino-1,5-dimethyl-2-phenyl-1,2-dihydro-3H-pyrazol -3-one with 2- amino 3- base, carboxaldehyde and characterized by $1 \mathrm{H}$ magnetic resonance, FT- IR, UV-Vis and EPR spectral studies. The complexes are of the kind $\mathrm{M}(-4 \mathrm{AAP}) 2$ [where $\mathrm{M}=\mathrm{Cu}(\mathrm{II}), \mathrm{Co}(\mathrm{II}))$,]. The metal atom is coordinated to atomic number 7 and element atoms of the Schiff base substance. The free substance and its metal complexes were screened for his or her medication activity. The results indicate that the copper complexes are having substance vital activity than its ligands against some microorganisms beneath identical experimental conditions. They additionally exhibit protein properties. All the fresh ready compounds were tested for inhibitor activity, the Schiff base substance and its metal complexes showed sensible activity.

\section{A. Hydrogen-1 NMR Spectra of Ligand (L1)}

The ${ }^{1} \mathrm{H}$ NMR spectrum of the ligand were recorded at room temperature in $\mathrm{CDCl}_{3}$. Using tetra methylsilane (TMS) as internal standard. The ${ }^{1} \mathrm{H}$ NMR spectrum shows the peaks at $6.2-7.2 \delta(\mathrm{m})$ shows the phenyl multiplet of Schiff base ligand (4.1) (Fig.3). The ligand similarly displays the signals as follows: $=\mathrm{C}-\mathrm{CH}_{3} 2.1-2.8(\mathrm{~s}) ;-\mathrm{CH}=\mathrm{N} 9.3 \delta(\mathrm{s})$ and 7.72 , 7.94and 7.983

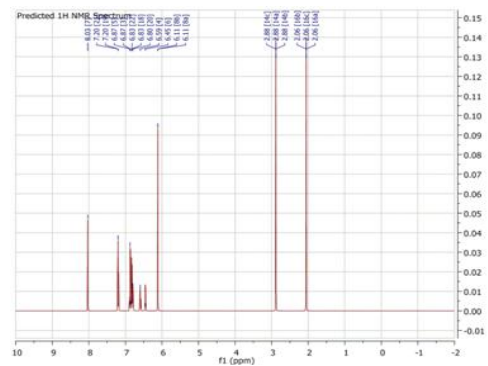

Fig.3. ${ }^{1}$ HNMR spectrum of the ligand(L1)(ppm in $\mathrm{CDCl}_{3}$ ) density Infrared spectra of the ligands and their metal complexes

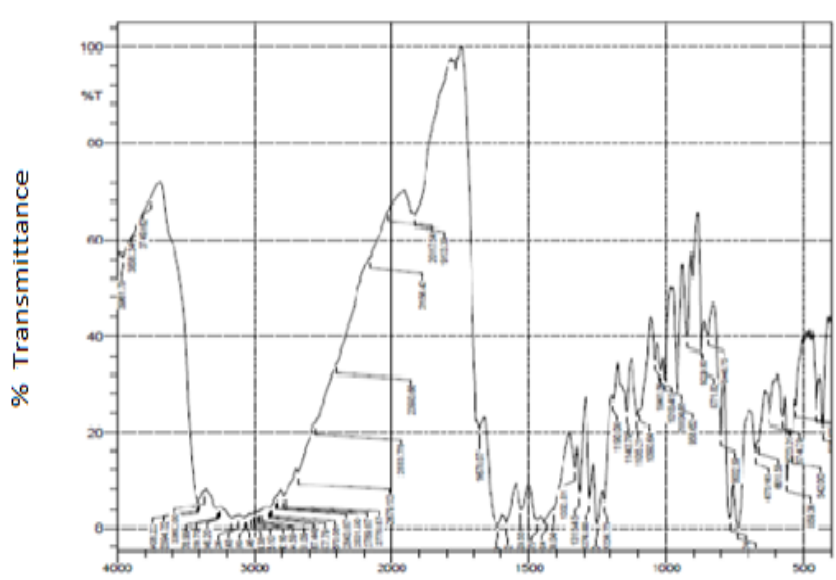

Wavelength $\mathrm{cm}-1$

Fig. 4. FT-IR Spectrum of Schiff base Ligand (L1)

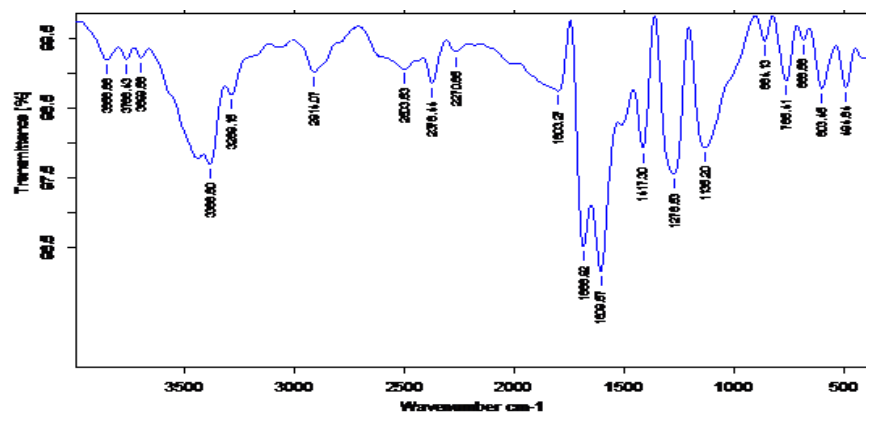

Fig.5. FT-IR Spectrum of Copper(II) metal Complex of L1

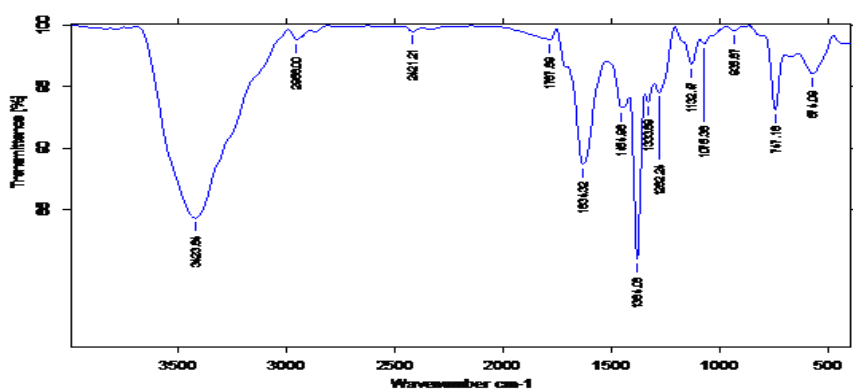

Fig.6.FT-IR Spectrum of Cobalt(II) metal Complex of L1

Published By:

Blue Eyes Intelligence Engineering

\& Sciences Publication 
Table 1. Physico chemical Properties of Ligand and Metal Complexes

\begin{tabular}{|c|c|c|c|c|c|c|}
\hline \multirow[t]{2}{*}{ Compound } & \multirow[t]{2}{*}{ Empricial formula } & \multirow{2}{*}{$\begin{array}{c}\text { Molecular } \\
\text { Weight }\end{array}$} & \multirow[t]{2}{*}{ Colour } & \multicolumn{3}{|c|}{$\begin{array}{l}\text { Elemental analysis \% } \\
\text { calc.(found) }\end{array}$} \\
\hline & & & & $\mathrm{C}$ & $\mathrm{H}$ & $\mathrm{N}$ \\
\hline Ligand & $\mathrm{C}_{17} \mathrm{H}_{17} \mathrm{~N}_{5} \mathrm{O}$ & 307.35 & $\begin{array}{l}\text { Light } \\
\text { brown }\end{array}$ & $\begin{array}{c}66.43 \\
(66.32)\end{array}$ & $\begin{array}{c}5.58 \\
(5.56)\end{array}$ & $\begin{array}{c}22.79 \\
(22.75)\end{array}$ \\
\hline $\mathrm{Cu}(\mathrm{L} 1)$ & $\mathrm{C}_{34} \mathrm{H}_{32} \mathrm{CuN}_{10} \mathrm{O}_{2}$ & 676.23 & Pale green & $\begin{array}{c}60.39 \\
(60.29)\end{array}$ & $\begin{array}{c}4.77 \\
(4.70)\end{array}$ & $\begin{array}{c}20.71 \\
(20.61)\end{array}$ \\
\hline $\mathrm{Co}(\mathrm{L} 1)$ & $\mathrm{C}_{34} \mathrm{H}_{32} \mathrm{CoN}_{10} \mathrm{O}_{2}$ & 671.62 & $\begin{array}{l}\text { Moss } \\
\text { green }\end{array}$ & $\begin{array}{c}60.80 \\
(60.78)\end{array}$ & $\begin{array}{c}4.80 \\
(4.75)\end{array}$ & $\begin{array}{c}20.86 \\
(20.65)\end{array}$ \\
\hline
\end{tabular}

Table 2. FT-IR Spectrum of ligand and its metal complexes (in $\left.\mathrm{cm}^{-1}\right)$

\begin{tabular}{ccccc}
\hline Compound & $v(C=N)$ & $v(C-O)$ & $v(M-N)$ & $v(M-O)$ \\
\hline Ligand (L1) & 1630 & 1315 & - & - \\
$\mathrm{Cu}(\mathrm{L} 1)$ & 1608 & 1216 & 768 & 603 \\
$\mathrm{Co}(\mathrm{L} 1)$ & 1621 & 1262 & 760 & 681
\end{tabular}

\section{B. Electronic spectra of ligand and its metal complexes}

The UV-Visible spectra area unit recorded in trichloromethane within the vary of $726 \mathrm{~nm}$ of the Schiff base. The UV-Vis. spectrum of the matter exhibits AN optical phenomenon at $355 \mathrm{~nm}$, which may be attributed to the $n-\pi^{*}$ transition of azomethine group. The molar absorptivity matter at $355 \mathrm{~nm}$ could also be allotted to AN transition between the lone-pair electrons of the $\mathrm{p}$ orbitals of the $\mathrm{N}$ atoms within the azomethine $(\mathrm{HC}=\mathrm{N})$ teams and therefore the $\pi$ bonds of the aromatic rings. The peaks at $276 \mathrm{~nm}$ area unit allotted to the $\pi-\pi *$ transitions of the Schiff base. In the gift case, the optical phenomenon within the $420 \mathrm{~nm}$ vary, that is allotted to a metal matter charge transfer band. The electronic spectrum of the $\mathrm{Cu}$ (II) complicated shows a broad band at $515 \mathrm{~nm}$ negotiable to transition that is characteristic of sq. planate surroundings.

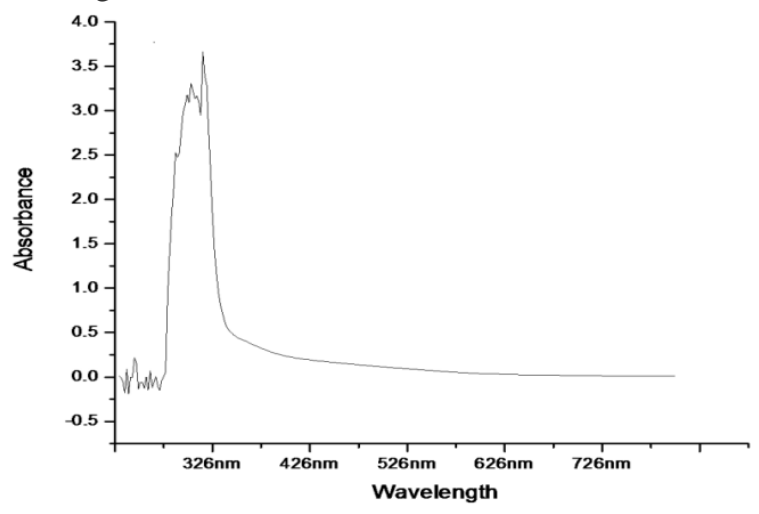

Fig.7.UV-visible Spectrum of Copper(II) metal Complex of $\mathrm{L1}$

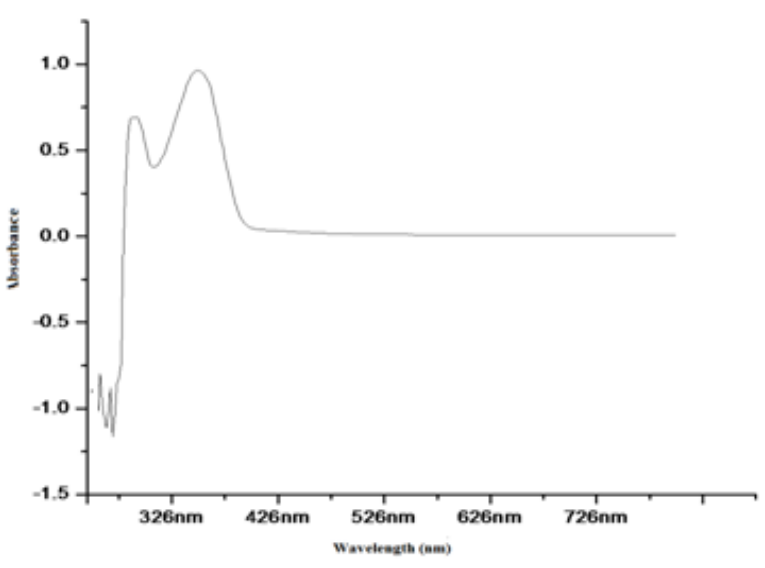

Fig.8. UV-visible Spectrum of Schiff base Ligand (L1)

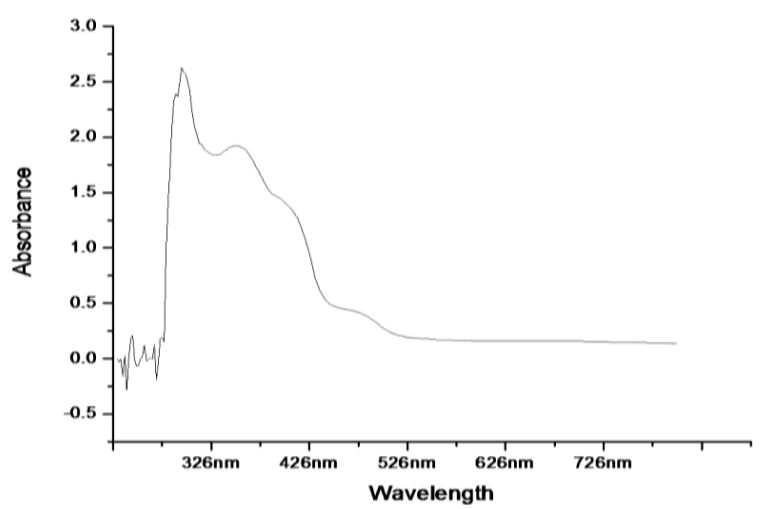

Fig.9.UV-visible Spectrum of Cobalt (II) metal Complex of $\mathrm{L} 1$ 


\section{Synthesis, Characterization and Analysis of Metal Complexes and their Inhibitor, and Anti-Microbial Activities}

Table 3.The spin Hamiltonian parameters of the $\mathrm{Cu}$ (II) complex at LNT

\begin{tabular}{cccccccc}
\hline \multirow{2}{*}{ Complex } & & g-tensor & \multicolumn{3}{c}{$\mathrm{A} \times 10^{-4}\left(\mathrm{~cm}^{-1}\right)$} \\
\\
\cline { 2 - 6 } & $\mathrm{g}_{\|}$ & $\mathrm{g}_{\square}$ & $\mathrm{g}_{\text {iso }}$ & $\mathrm{A}_{\|}$ & $\mathrm{A}_{\square}$ & $\mathrm{G}$ \\
\hline \multirow{2}{*}{ copper } & 2.28 & 2.08 & 2.15 & 158 & 88 & 112 & \\
\hline
\end{tabular}

Table 4. Minimum inhibition concentration (MIC) $\mu \mathrm{g} / \mathrm{ml}$ data of the synthesized ligand and metal complexes against growth of bacteria

\begin{tabular}{cccc}
\hline & \multicolumn{3}{c}{ Minimum Inhibition Concentration (MIC) } \\
\hline Compound & Salmonellatyphi & KlebsiellaPneumonia, & $\begin{array}{c}\text { Staphylococci } \\
\text { aureus }\end{array}$ \\
\hline $\begin{array}{c}\text { Standard(Amikacin) } \\
\text { Ligand (L1) }\end{array}$ & 17 & 18 & 16 \\
$\mathrm{Cu}(\mathrm{L} 1)$ & 16 & 16 & 17 \\
$\mathrm{Co}(\mathrm{L} 1)$ & 12 & 10 & 6 \\
& 16 & 10 & 7
\end{tabular}

\section{Electron Paramagnetic Resonance Spectra}

The X-band EPR spectrum of the copper (II) complicated (1) was recorded in Dimethyl sulphoxide at atomic number 7 temperature (LNT). It showed four lines with nuclear thin spin $3 / 2$ because of thin cacophonic. The spin Hamiltonian parameters of complicated (1) were calculated. The determined $\mathrm{g} \|$ values were indicating extensive valence character within the $\mathrm{M}-\mathrm{L}$ bonds [15]. The trend $\mathrm{A}\left\|(158)>\mathrm{A}_{\perp} \quad(88) ; \mathrm{g}\right\|\left(2.28>\mathrm{g}_{\perp}(2.08)>\right.$ 2.0027 indicate that the odd negatron was placed within the $\mathrm{dx}-\mathrm{y}$ orbital (B1g state) to imagine a sq. plate like pure mathematics around $\mathrm{Cu}(\mathrm{II})$ ions [5]. The axial symmetry parameter $\mathrm{G}$ is plot as in condition four.1.According to Hathaway [5], if the $G$ worth > four, the trade communication is unimportant, while a cost is < four gives a sign to right shrewd trade connection inside the progressed. The axial symmetry parameter $(\mathrm{G})$ of the reputed metallic component (II) progressed was $>$ four (4.8) recommending that the local polygonal shape tomahawks were adjusted parallel or somewhat skewed and thusly the odd negatron is blessing inside the $d x-y$ orbital. This outcome conjointly demonstrates that the trade coupling impacts aren't usable inside the blessing progressed

Theaxial symmetryparameter Gis definedasin equation 1.

$$
\mathrm{G}=\frac{\mathrm{g}_{\|}-2.0023}{\mathrm{~g}_{\perp}-2.0023}
$$

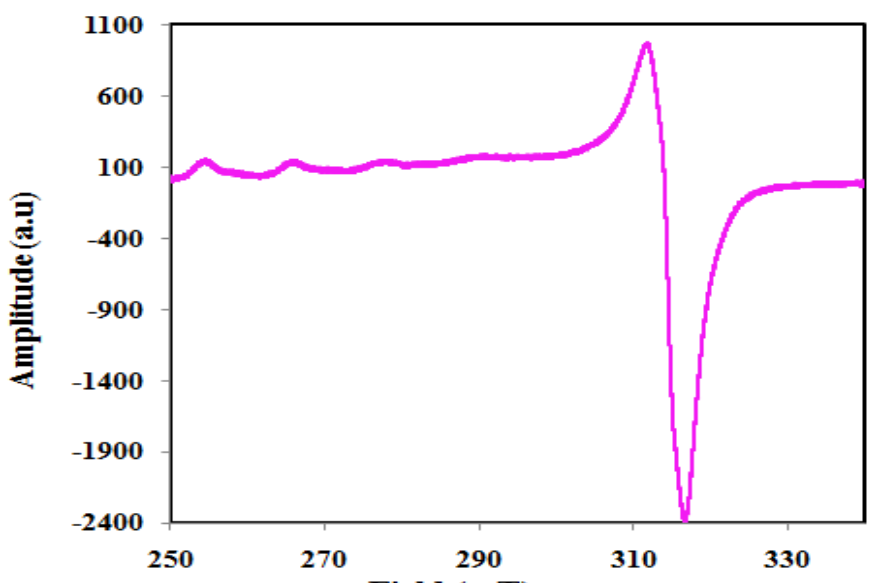

Fig.10. EPR spectrum of $\mathrm{Cu}(\mathrm{II})$ metal complex at LNT.

\section{D.Anti-bacterial activity}

The results of the antibacterial drug and antifungal activity shown. Dimethyl sulfoxide was used as a negative management and Amikacin was used as positive standards for antibacterial drug studies. The matter and metal complexes show bigger antimicrobial activity than those of the management drug; this means that the complexation with metal enhances the activity of the matter. this can be explained on the premise of Overtone's conception and chelation theory. Chelation tends to create the matter a additional powerful and potent microorganism agent. A attainable rationalization for this increase within the activity upon chelation is that, during a chelate complicated, the charge of the metal is partly shared with donor atoms gift within the ligands associated there's an

lepton delocalization over the full chelate ring. This, in turn, will increase the 
macromolecule layers of the microorganism membranes. Generally, it's urged that the chelate complexes deactivate numerous cellular enzymes, that play an important role in numerous metabolic pathways of those microorganism. The synthesized compounds exhibit moderate to robust antimicrobial activity. The variation within the effectiveness completely different of various compound against different organisms depended either on the solidness of the cells of the microbes or on variations in ribosome of microorganism cells. The $\mathrm{Cu}$ (II) complicated and $\mathrm{Co}(\mathrm{II})$ complicated exhibit a better activity

\section{E. Anti-fungal activity}

To outfit a refreshing degree inside the field of bioinorganic chemistry, therefore, the steel edifices blended are assessed for their antifungal activities. The antifungal checks have been dispensed misuse the plate dispersion philosophy. The Schiff base ligands and their metallic edifices have been screened in vitro to scanning for out the antifungal action against parasite sort niger, Candidatrophicala and Moniliaalbicans. The results of the antifungal investigations that uncover that the copper buildings having higheractivity contrary to the organisms $\mathrm{C}$. trophicalis. similarly the metallic factor troublesome in this way higher entertainment than the substance towards the parasites A. nigeractivity. the C.albicans show brilliant exercise for the metal edifices, on the grounds that the scope of group inside the substance will build, it'll decline anti-fungicidal of the buildings. the upward push inside the antifungal movement of the metal edifices hinders increase strategy of the organisms by block their dynamic locales. Such misrepresented undertaking on metallic chelation are frequently clarified on the idea of Tweedy chelation hypothesis. Incorporated compounds having aminoalkanoic corrosive moieties conjointly show shrewd movement.

\section{$F . D P P H$ radical scavenging assay}

The free 2,2-diphenyl-1-picrylhydrazyl. radical-scavenging is reported that the decrease within the absorbance of DPPH radical that's caused by phenoplast compounds is as a result of the reaction between inhibitor molecules and radicals. This leads to the scavenging of the novel by atomic number 1 donation and is pictured as a discoloration from deep-violet to lightweight yellow color. The complexes show higher scavenging ability compared to the substance. These 2 aspects (1) The building block chemical bond of the phenoplast teams Ohio within the substance is broken the complexes, it will lose its atom to react with the DPPH radicals and will increase the scavenging activity compared with substance. (2) coordinating to the advanced particle, the substance modified from keto to organic compound kind that shows a giant conjugating system within the complexes. This reduces the bond of the Ohio teams and makes it react with DPPH radicals, so the scavenging impact is magnified.

\section{CONCLUSION}

The present examination depicts the union of ongoing Schiff bases inferred from4-aminoantipyrine and 2-amino 3-soluble base. The EPR study affirms the structure of new incorporated Schiff bases. The spectral information shows that the Schiff bases go about as monobasic unpleasant NO chelating specialists coordinative the metal molecule by means of the azomethine component particle and likewise the engineered tar concoction component iota. Further, the promising outcomes are discovered for the antimicrobial screening especially for the metal edifices against each the organisms and bacterium and likewise the outcomes zone unit ascribed to the very truth that the metal buildings region unit surely dynamic against microorganism cells and parasites cells. seeable of the natural movement, copper and Co edifices have demonstrated a superior action.In future research f-block metals will be considered.

Table 5. Minimum inhibition concentration (MIC) $(\mu \mathrm{g} / \mathrm{ml})$ data of the synthesized ligand and metal complexes against growth of fungi

\begin{tabular}{cccc}
\hline \multirow{2}{*}{ Compound } & \multicolumn{3}{c}{ Minimum Inhibition Concentration } \\
\cline { 2 - 4 } & Candidiatrophicalis & Aspergillus & Candidaalbicans \\
\hline Standard(Ketakonazole) & 17 & 18 & 16 \\
Ligand (L1) & 16 & 16 & 17 \\
Cu(L1) & 16 & 10 & 13 \\
Co(L1) & 10 & 8 & 10
\end{tabular}




\section{Synthesis, Characterization and Analysis of Metal Complexes and their Inhibitor, and Anti-Microbial Activities}

Table 6. \% of antioxidant of ligand and its metal complexes

\begin{tabular}{|ccc|}
\hline Concentration( $\boldsymbol{\mu} \mathbf{g} / \mathbf{m l})$ & $\mathbf{L 1}$ & $\mathbf{C u}(\mathbf{L} \mathbf{1})$ \\
\hline 100 & 9.3 & 2.1 \\
200 & 15.6 & 10.5 \\
300 & 39.0 & 16 \\
400 & 45.3 & 25 \\
500 & 56.2 & 26 \\
\hline
\end{tabular}

\section{REFERENCES}

1. S. Yamada, Coord. Chem. Rev., 196 (1999) 537.

2. T. Taniguchi, , T. Nabeshima, J. Org. Chem. 77 (2005) 1704.

3. Y.-X. Sun, etal. Tong, Inorg. Chim. Acta., 352 (2009) 137.

4. E.-Q. Gao, Z.-M. Wang, C.-H. Yan, Chem. Commun., (2003) 1748.

5. I. Goldberg, Cryst. Growth Des., 3 (2003) 321.

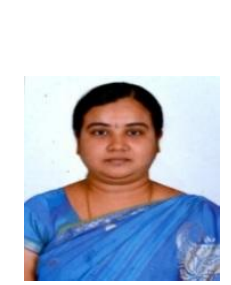

\section{AUTHOR'S PROFILE}

Dr.N.Srividhya, working as Assistant Professor in the Department of Chemistry, at PSNA College of Engineering and Technology, Dindigul,TamilNadu, India. I have completed my UG Under Madurai Kamaraj University and PG under Anna Univeristy. I completed my M.phil under Prist university and Ph.D under Madurai Kamaraj University. I have published 10 papers in reputed journals and have presented around 12 papers in National and international conference.

Mail id vidhyahari11@gmail.com, cell no :9944024056

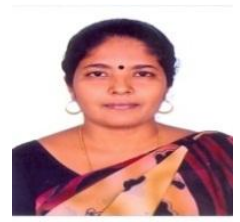

Dr. Ignatius NavisKarthika, working as Assistant Professor in the Department of Chemistry, at PSNA College of Engineering and Technology, Dindigul,TamilNadu, India. I have completed my UG Under ManonmanianSundararam University and PG under Gandhi gram Deemed University. I completed my M.phil under Bharathiasan University and Ph.D under Bharathiyar University. I have published 12 papers in reputed journals in my displine and have presented around 20 papers in National and international conference.

Mail id i.n.karthika@gmail.com cell no : 758102216

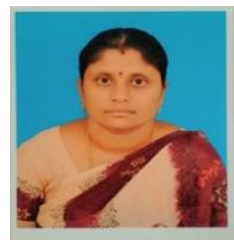

Dr.K.Kavipriya, working as Assistant Professor in the Department of Chemistry, at PSNA College of Engineering and Technology, Dindigul, Tamilnadu, India. I have completed my UG Under Madurai Kamarajar University and PG under Madurai Kamaraj University. I completed my M.phil under Bharathiasan University, and Ph.D Madurai Kamaraj University under I have published 12 papers in reputed journals in chemistry displine and have presented around 10 papers in National and international conference.

Mail id seenikavi@yahoo.co.in cell no 9976364090 